\title{
CSAPÁGYHIBÁK DIAGNOSZTIZÁLÁSÁRA ALKALMAS MÓDSZEREK KUTATÁSA
}

\author{
Tóth Dániel \\ tanársegéd, Miskolci Egyetem, \\ Szerszámgépészeti és Mechatronikai Intézet, Szerszámgépek Intézeti Tanszéke \\ 3515 Miskolc, Miskolc-Egyetemváros, e-mail: toth.daniel@uni-miskolc.hu \\ Takács György \\ egyetemi docens, Miskolci Egyetem, \\ Szerszámgépészeti és Mechatronikai Intézet, Szerszámgépek Intézeti Tanszéke \\ 3515 Miskolc, Miskolc-Egyetemváros, e-mail:takacs.gyorgy@uni-miskolc.hu \\ Szilágyi Attila \\ egyetemi docens, Miskolci Egyetem, \\ Szerszámgépészeti és Mechatronikai Intézet, Szerszámgépek Intézeti Tanszéke \\ 3515 Miskolc, Miskolc-Egyetemváros, e-mail: szilagyi.attila@uni-miskolc.hu

\begin{abstract}
Simon Gábor
mesteroktató, Miskolci Egyetem,

Szerszámgépészeti és Mechatronikai Intézet, Szerszámgépek Intézeti Tanszéke

3515 Miskolc, Miskolc-Egyetemváros, e-mail: simon.gabor@uni-miskolc.hu
\end{abstract}

\begin{abstract}
Absztrakt
A csapágyaknak, mint az egyik leggyakoribb gépelemeknek, minden forgógépben kimagasló szerepük van. Olyan meghibásodási sorozatot indithat el a csapágyazás hibája a berendezésekben, amelyek akár több nagyságrenddel meghaladhatják a csapágycsere, illetve a diagnosztikai vizsgálat költségeit is. A csapágyhibák korai észlelése lehetövé teszi, hogy kicseréljük a csapágyat a tervezett karbantartás során, így elkerülhetö a berendezés váratlan leállása a csapágy meghibásodása miatt.
\end{abstract}

Kulcsszavak: csapágykárosodások, gördülöcsapágy, hibavizsgálat

\begin{abstract}
Bearings can be found widely in domestic and industrial applications. They are important components of most machinery and their working conditions influence the operation of the entire machinery directly. Bearing failures may cause machine breakdown and might even lead to catastrophic failure or even human injuries. In order to prevent unexpected events, bearing failures should be detected as early as possible.
\end{abstract}

Keywords: bearing failures, roller element bearing, fault detection

\section{Bevezetés}

A csapágyak kutatása az évek során a tudomány egy különleges ágává fejlődött. Sajnos előfordul néha, hogy a csapágy nem éri el kiszámított névleges élettartamát. Ennek oka lehet például a számítottnál nagyobb terhelés, a nem elegendő vagy nem megfelelő kenés, a gondatlan kezelés, a rossz hatásfokú 
Tóth, D., Takács, Gy., Szilágyi, A., Simon, G. C Csapágyhibák diagnosztizálására alkalmas módszerek kutatása

tömítés vagy a túl szoros illesztések, melyek elégtelen belső csapágyhézagot eredményezhetnek. Különféle technikák léteznek a csapágyak müködési viszonyainak felügyeletéhez, amelyek segítenek meghatározni a csapágyhiba megjelenését. Elterjedt diagnosztikai módszerek a kenőanyag vizsgálat, a zajdiagnosztika, az akusztikus emisszió, a kopási hulladékelemzés, a hőmérsékletelemzés és a csapágyrezgések vizsgálata [1].

\section{Csapágyhibák}

A csapágykárosodások jellegzetes hibákat okoznak, melyeket elsődleges és másodlagos meghibásodásokra szokás osztani (1. táblázat).

1. táblázat. Csapágyak tönkremenetelének típusai

\begin{tabular}{|c|c|}
\hline Tönkremenetel módja & Lehetséges okok \\
\hline Kopás & $\begin{array}{ll}\text { - } & \text { Kenőanyag hiánya } \\
\text { - } & \text { Szennyezett szerelési környezet } \\
\text { - } & \text { Rossz tömítés } \\
\text { - } & \text { Tengelybeállási hiba }\end{array}$ \\
\hline Benyomódás & $\begin{array}{ll}\text { - } & \text { Helytelen szerelés } \\
\text { - } & \text { Túlterhelés álló állapotban } \\
\text { - } & \text { Kúpos furatú csapágyak túlzott előfeszülése } \\
\text { - } & \text { Tengelybeállási hiba } \\
\text { - } & \text { Idegen részecskék } \\
\end{array}$ \\
\hline Elkenődés & $\begin{array}{l}\text { - } \text { Nagy axiális terhelés } \\
\text { - } \quad \text { Kenőanyag hiánya } \\
\text { - } \quad \text { A görgő megcsúszása a terhelési zónában } \\
\text { - Helytelen szerelés (impulzív behatás) } \\
\text { - } \quad \text { Rossz illesztés következtében a külső gyürü elforog a házban }\end{array}$ \\
\hline Korrózió & $\begin{array}{ll}\text { - } & \text { Helytelen raktározás } \\
\text { - } & \text { Víz jelenléte a csapágyban } \\
\text { - } & \text { Illesztési korrózió laza illesztés és/vagy alakhiba következtében } \\
\end{array}$ \\
\hline Átmenő villamos áram & - Villamos áram áthaladása a gyürükön \\
\hline Pitting & $\begin{array}{l}\text { - } \quad \text { Tengelybeállási hibából eredő túlterhelés } \\
\text { - } \quad \text { Elégtelen kenés } \\
\text { - } \quad \text { Túl szoros illesztésből adódó előfeszülés } \\
\text { - } \quad \text { Gyürük közötti nagy hőmérsékletkülönbség } \\
\text { - } \quad \text { Tengely vagy csapágygyürü alakhibája } \\
\text { - } \quad \text { Mélyrozsda okozta } \\
\text { - } \quad \text { Benyomódásból eredő }\end{array}$ \\
\hline Repedés & $\begin{array}{ll}\text { - } & \text { Helytelen szerelés (impulzív behatás) } \\
\text { - } & \text { Kúpos furatú csapágyak túlzott előfeszülése } \\
\text { - } & \text { Helytelen illesztés } \\
\text { - } & \text { Elkenődés okozta repedések } \\
\text { - } & \text { Illesztési korrózió laza illesztés és/vagy alakhiba következtében }\end{array}$ \\
\hline Kosárszerkezet tönkremenetel & $\begin{array}{ll}\text { - } & \text { Rezgések } \\
\text { - } & \text { Túlzott fordulatszám } \\
\text { - } & \text { Koptató részecskék jelenléte }\end{array}$ \\
\hline
\end{tabular}


Az elsődleges hibák közé sorolható a kopás, az elkenődés, a felületi károsodás, a benyomódás, a korrózió és a villamos áram okozta károsodás. A primer károsodás tovább terjedéseként jelentkezhetnek a szekunder károsodások, mint például a repedés és a lepattogzás. A csapágyak korai tönkremenetelének oka lehet például a gondatlan kezelés, a számítottnál nagyobb terhelés, a nem elegendő vagy nem megfelelö kenés, a rossz hatásfokú tömítés vagy a túl szoros illesztések, melyek elégtelen belső csapágyhézagot eredményeznek. Egy károsult csapágyat megvizsgálva a legtöbbször véleményt lehet formálni a hiba okáról és ezt követően a szükséges intézkedéseket meg lehet tenni [2].

\section{Müszeres kenőanyag-vizsgálat}

Azoknál a berendezéseknél, ahol a gépelemek közvetlen vizsgálata csak teljes szétszerelés árán lehetséges, az olajban lévő részecskék vizsgálata a meghibásodások korai felismerése céljából jól hasznosítható. A müszeres kenőanyag-vizsgálattal a kenőanyagban megjelenő kopástermékek mutathatók ki, valamint a kenőanyag minősítése végezhető el. A módszer az alkalmazott kenőanyag fizikai és kémiai jellemzőinek meghatározásán keresztül számszerüsíti a korrózióval kapcsolatos meghibásodás mértékét. Ilyen számszerüsíthető adat például a kenőanyag viszkozitása, víztartalma, savszáma, illetve szennyezettsége, oxidációs foka, valamint adaléktartalma ( $\mathrm{Ca}, \mathrm{Zn}, \mathrm{P}, \mathrm{Fe}, \mathrm{Cr}, \mathrm{Sn}, \mathrm{Al}, \mathrm{Cu}, \mathrm{Pb}, \mathrm{Ni}$, stb.). E tényezők trendszerü felvétele enged következtetni bizonyos tönkremeneteli formákhoz köthető remanens élettartamra. A részecskevizsgálat legnagyobb szakértelmet igénylő része a nyert adatok alapján a tönkremeneteli folyamatokra végzett becslés és a diagnózis meghatározása. Ezt számítógépes szakértői rendszerrel szokták megoldani, amely képes a paramétereket összefüggésében elemezni [3].

\section{Zajdiagnosztika}

A csapágy belsejében forgó görgők illetve golyók által szélessávú zaj és rezgés keletkezik, amely fokozódik a csapágy helytelen kenése, túlterheltsége (pl. egytengelyüség-beállítási hiányosságok) következtében, vagy a futófelületek, illetve a gördülőelemek felületeinek meghibásodása esetén. A zajvizsgálat során a hangtér két jellemzőjét szokták detektálni: a hangnyomást és a hangintenzitást. A rezgésdiagnosztikával szembeni jelentős előnye, hogy a zajkeltő objektummal nem kell közvetlen kapcsolatot teremteni, a zajmérés bizonyos távolságból is elvégezhető. A zajmérésnél nehezebb szétválasztani a diagnosztikai információt hordozó összetevőket az érdektelen részektől vagy esetleg a külső zavaró körülményektöl. Bár a csapágy zajdiagramjának felvétele nem ad lehetőséget egyértelmü gyártási, illetve technológiai hiba kiszürésére, a zajmérés és ezen belül is az úgynevezett effektív zajérték kiválóan alkalmas a csapágy minősítésére, hiszen a csapágyzajban valamennyi technológiai és gyártási hiba érezteti hatását. Megfelelő hangszigetelés hiányában a háttérzaj jelentős mértékben rontja a vizsgált csapágyzaj detektálhatóságának hatékonyságát, ezért célszerủ hangszigetelt, visszhangmentes, direkt ilyen célra kialakított helyiségben végrehajtani a vizsgálatot. A mért zajszintet nemcsak a csapágy, hanem a méréshez használt készülék is befolyásolja, ezért a különböző zajvizsgáló berendezéseken kapott mérési értékeket nehéz egymással összehasonlítani. Ennek ellenére egy szerelt csapágy minősítésére - frekvencia analizátor alkalmazása esetén - a csapágy zajdiagramjából levonhatók bizonyos következtetések [4].

\section{Akusztikus emisszió}

Akusztikus emissziónak (AE) nevezik az anyag belső szerkezetében felhalmozott, belső energia felszabadulásakor keletkező rugalmas hullámokat. Az üzemi terhelés alatt lévő forgó golyók, illetve gör- 
gők AE forrásként müködnek, amelyet a csapágyházra helyezett érzékelővel lehet detektálni. A módszer által használt mérőlánc általában egy piezoelektromos jelátalakítót, egy előerősítőt, valamint egy jelanalizátort tartalmaz. A jelátalakító, melynek sajátfrekvenciája igen magas, rezonanciára érzékeny. Az előerősítőben lévő, alkalmasan megválasztott sávszürő a jelátalakító jelét módosítja. Az általa elöállított leggyakoribb AE paraméterek a hullámszám (ringdown count), az esemény (event) és a csúcsérték (peak amplitude). Az AE paraméterek segítségével egy defektus már akkor kimutatható, mielőtt még az megjelenne a rezgésgyorsulás spektrumban, ráadásul élettartam vizsgálatok során is képes kimutatni az AE forrásokat [5].

\section{Rezgésdiagnosztika}

A rezgésdiagnosztika alkalmazásával a szerkezet megbontása vagy leállítása nélkül bármikor megállapítható a kérdéses egység várható élettartama, károsodásának mértéke, pillanatnyi állapota, majd ezek alapján egy esetleges beavatkozás szükségessége és ennek időpontja az üzemeltetés függvényében [6]. A gördülőcsapágyak rezgésdiagnosztikai vizsgálataira különféle idö-, és frekvenciatartományon elvégezhető jelanalizálási technikák léteznek. Helyi defektusok időtartományon való kimutatása úgy is lehetséges, hogy a rezgést monitoron jelenítik meg, esetleg kinyomtatják diagram formájában, majd ezeken olyan amplitúdó kiugrásokat figyelnek meg, amelyek egy-egy jellegzetes helyi defektushoz köthetők [7].

\section{7. Összefoglalás}

A gépállapot felmérések egyik lényeges eleme a csapágyak állapotának vizsgálata, hiszen ezen alkatrészek kiemelt fontossággal bírnak valamennyi forgógépben. Jelen cikk keretei között csapágyhibák feltárására alkalmas diagnosztikai módszereket mutattunk be.

\section{Köszönetnyilvánítás}

A cikkben ismertetett kutató munka az EFOP-3.6.1-16-2016-00011 jelü „Fiatalodó és Megújuló Egyetem - Innovatív Tudásváros - a Miskolci Egyetem intelligens szakosodást szolgáló intézményi fejlesztése" projekt részeként - a Széchenyi 2020 keretében - az Európai Unió támogatásával, az Európai Szociális Alap társfinanszírozásával valósul meg.

\section{Irodalom}

[1] P. P. Kharche, S. V. Kshirsagar: Review of Fault Detection in Rolling Element Bearing. IJIRAE, Vol. 1 Issue 5, June 2014.

[2] S. Patidar, P. K. Soni: An Overview on Vibration Analysis Techniques for the Diagnosis of Rolling Element Bearing Faults. IJETT, May 2013.

[3] Eugene Matzan: Detecting Premature Bearing Failure. Machinery Lubrication magazine, May 2007.

[4] Patkó Gy., Takács Gy., Demeter P., Barna B., Hegedűs Gy., Barak A., Simon G., Szilágyi A.: A process for establishing the remanent lifetime of rolling element bearings. XXIV. Microcad international scientific conference, Miskolc - Egyetemváros, 2010. 
Tóth, D., Takács, Gy., Szilágyi, A., Simon, G. $\quad$ Csapágyhibák diagnosztizálására alkalmas módszerek kutatása

[5] Yongyong He, Xinming Zhang, Michael I. Friswell: Defect diagnosis for rolling element bearings esing acoustic emission. J. Vib. Acoust. Dec 2009, 131(6):061012. https://doi.org/10.1115/1.4000480

[6] Dömötör Ferenc: Rezgésdiagnosztika I. Dunaújváros, 2008.

[7] Tóth Lajos Tibor: Tranziens és kváziperiodikus folyamatok analízise az idő-frekvencia tartományban. PhD értekezés, Miskolc, 2011. 